\title{
Uspostava i razvoi hrvatskog sustava kontrole kvalitete drvnih ploča utemelienog na europskoj tehničkoj regulativi
}

\section{Establishment and Development of Croatian Quality Control System for Wood-Based Panels in Accordance with European Technical Regulations}

\author{
Stručni rad • Professional paper \\ Prispjelo-received:16. 1. 2010. \\ Prihvaćeno-accepted:25. 2. 2011. \\ UDK: $630 * 863.2$ \\ doi:10.5552/drind.2011.1001
}

\begin{abstract}
SAŽETAK • Nakon osamostaljenja Republike Hrvatske (RH) osnovni gospodarski cilj bio je uključenje na međunarodno tržište i ulazak u Europsku uniju (EU). S razvojem vanjskotrgovinskih odnosa bilo je nužno uspostaviti sustav kontrole kvalitete drvnih ploča, a taj proces počinje u sklopu Državnog zavoda za normizaciju $i$ mjeriteljstvo (DZNM). Pod ingerencijom DZNM-a provodi se edukacija, ovlašćivanje, osnivanje i rad tehničkih odbora (TO), donose se novi propisi te obavlja implementacija europskoga tehničkog zakonodavstva. Prema Naredbi o obaveznom certificiranju ploča iverica za opću uporabu i graditeljstvo (Sl. list 61/83), DZNM ovlastio je godine 1995. Šumarski fakultet za obavljanje poslova certificiranja ploča iverica. Ministarstvo gospodarstva također se uključilo u izgradnju sustava, pa je krajem 1998. godine na području drvnih ploča izgrađen respektabilan sustav kontrole kvalitete. Sljedeći korak bila je izrada tehničkih propisa i implementacija europskih normi. No tada slijede potezi zbog kojih dolazi do potpunog raspada sustava, koji početkom 2004. godine više praktički ne postoji. Ministarstvo gospodarstva i Vlada Republike Hrvatske ukidaju sve odluke o kontroli kvalitete drvnih ploča, osim obveznog certificiranja ploča iverica, koje je pod ingerencijom DZNM-a, a on prestaje raditi tijekom 2003. godine. Ministarstvo zaštite okoliša, prostornog uređenja i graditeljstva (MZOPUG) kao nadležna institucija preuzima 2005. godine potvrđivanje ploča iverica, a potom u tehničku regulativu za graditeljstvo uvodi europske norme za drvne ploče. No potvrđivanje ploča iverica i dalje se obavlja prema normama bivše države. U pokušaju donošenja Tehničkog propisa za drvne ploče, koji je iniciralo Ministarstvo regionalnog razvoja, šumarstva $i$ vodnoga gospodarstva (MRRŠVG), nije postignut konsenzus zbog primjene drvnih ploča $i$ za opće uporabe $i$ na području graditeljstva.
\end{abstract}

Ključne riječi: drvne ploče, kontrola kvalitete, TO 89, tehnički propis, europske norme

\footnotetext{
Autori su, redom, izvanredni profesor, docent i asistent na Šumarskom fakultetu Sveučilišta u Zagrebu, Zagreb, Republika Hrvatska. ${ }^{2}$ Autor je mag. ing. techn. lign., zaposlenik tvrke Drvna industrija Novoselec d.o.o., Novoselec, Republika Hrvatska.

Authors are associated professor, assistant professor and assistant at Faculty of Forestry, University of Zagreb, Croatia. ${ }^{2}$ Author is Master of Engineering in wood technology, employee of the wood industry company Novoselec d.o.o., Novoselec, Republic of Croatia.
} 
ABSTRACT - After reaching its independence, Croatia's (CRO) main economic goal was to enter the international market and join the European Union (EU). As foreign trade relations developed, it was necessary to establish a quality control system for wood-based panels. The development of the quality system started at the State Office for Standardization and Metrology (SOSM). The Faculty of Forestry was intensively involved in all activities related to the establishment of the quality system, such as the establishment of testing laboratories, education, certification, quality control, work in technical committees, and special activities were directed towards the implementation of technical regulations in wood technology practice. The system was first introduced by the Order of obligatory certification of particleboard panels for general use and construction (Official Gazette "Sl. list" 61/83), based on laws of the former state. In accordance with the Order, in 1995 SOSM authorized the Faculty of Forestry for conducting the certification of particleboards. The Ministry of Economy was also included in the development of the system in areas not covered by the Order and regulations under SOSM's jurisdiction. In the field of wood-based panels, a respectable system was built by the end of 1998. The next step was the preparation of technical regulations with the implementation of harmonized European standards. However, for reasons beyond understanding, the system completely collapsed, and in early 2004 it practically ceased to exist. The Ministry of Economy and the Croatian Government abolished all decisions on quality control of wood-based panels, except the obligatorily certification of particleboards performed by SOSM, and it stopped its activities in 2003. The Ministry of Environmental Protection, Physical Planning and Construction (MEPPPC), as the competent institution, took over the certification of particleboards after a whole year of lack of any quality control of wood-based panels, and implemented the European standards for particleboards into technical regulations for construction. However, the certification of particleboards is still performed in accordance with standards of the former state. In the attempt to enact the Technical Regulation for wood-based panels, initiated by the Ministry of Regional Development, Forestry and Water Management (MRDFWM), no consensus was reached, due to the application of wood-based panels both in the area of general use and in the field of construction.

Key words: wood-based panels, quality control, TC 89, technical regulation, European standards

\section{UVOD}

\section{INTRODUCTION}

Drvne su ploče jedan od najvažnijih materijala $u$ razvoju drvnoindustrijskog kompleksa, što je vidljivo iz svih statističkih podataka, ali i iz vizije razvoja europskoga gospodarstva utemeljenoga na šumskim proizvodima (Hägglund i sur., 2005). Za razvoj industrije finalnih drvnih proizvoda Republike Hrvatske (RH) drvne su ploče od iznimnog značaja. Od osamostaljenja RH njezino je tržište gotovo potpuno otvoreno, što dovodi do intenzivnog uvoza drvnih ploča. Otvoreno tržište omogućilo je i uvoz drvnih ploča neadekvatne kvalitete, deklariranih kao visokovrijedni proizvodi. Prvi korak u uspostavi sustava kontrole kvalitete drvnih materijala jest donošenje Zakona o standardizaciji (NN 53/91; 26/93; 29/94 i 25/96), kojim je, među ostalim, iz zakonodavstva bivše države u hrvatsko zakonodavstvo ugrađena Naredba o obaveznom atestiranju ploča iverica za opću upotrebu i građevinarstvo (S1. list 61/83). Preuzimanjem Naredbe ploče iverice postale su jedini proizvod za koji se izdavao certifikat (od 1995. godine), odnosno potvrda o sukladnosti (od 2005. godine) i koji je imao pravo nositi certifikacijski znak, prema Pravilniku o izgledu i upotrebi potvrdbenog (certifikacijskog) znaka (NN 88/98; 165/98; 8/99).

Sukladno odredbama Zakona o izmjenama i dopunama Zakona o ustrojstvu republičke uprave (NN 73/91), ustrojen je Republički zavod za normizaciju i mjeriteljstvo, koji kasnije nastavlja plodan rad pod nazivom Državni zavod za normizaciju i mjeriteljstvo (DZNM), u skladu sa Zakonom o ustrojstvu i djelokrugu ministarstava i drugih organa državne uprave (NN 55/92). Tijekom 1993. godine osnovan je na Šumarskom fakultetu u Zagrebu, na Drvnotehnološkom odsjeku, na Katedri za mehaničku preradu drva, Laboratorij za drvne ploče (LAP), koji započinje intenzivne aktivnosti u kontroli kvalitete drvnih ploča.

\section{USPOSTAVA SUSTAVA KONTROLE KVALITETE DRVNIH PLOČA}

2 ESTABLISHMENT OF WOOD-BASED PANEL QUALITY CONTROL SYSTEM

DZNM 15. svibnja 1995. godine donosi rješenje o ovlaštenju Šumarskog fakulteta za obavljanje kontrole kvalitete ploča iverica, čime ujedno započinje njihova sustavna kontrola. U uspostavu sustava kvalitete uključuje se i Ministarstvo gospodarstva, koje donosi Odluku o proglašenju Zakona o nadzoru kakvoće određenih proizvoda pri uvozu i izvozu (NN 21/95). Ministarstvo gospodarstva također donosi Pravilnik o načinu i postupku obavljanja nadzora kakvoće određenih proizvoda pri uvozu i izvozu (NN 42/96). U popisu niza proizvoda za koje se uvjerenje može izdati samo na temelju prethodno provedenog ispitivanja nalaze se furniri i ploče, a jedna od stručnih organizacija koja može obavljati ispitivanje kakvoće furnira i drvnih ploča jest Šumarski fakultet, Zavod za istraživanja u drvnoj industriji (ZIDI), u čijem je sastavu bio LAP. Novi korak u uključivanju u europski sustav kontrole kvalitete drvnih ploča bilo je donošenje Pravilnika o uvjetima i načinu priznavanja izvještaja o ispitivanju izdanih u inozemstvu i izdavanja potvrda o sukladnosti (NN 69/97). Glavna zapreka u postupku priznavanja bile su međunarodne norme, koje u Republici Hrvatskoj nisu bile prihvaćene.

Na temelju Zakona o normizaciji (NN 55/96), ravnatelj DZNM-a donosi Pravilnik o općim uvjetima 
koje moraju zadovoljiti ovlašteni laboratoriji i ovlaštene pravne osobe za provedbu potvrđivanja i o načinu provedbe postupka ovlašćivanja (NN 83/98). Opći uvjeti za dobivanje ovlaštenja koje moraju zadovoljiti laboratoriji određeni su normom HRN EN 45001 - Opći kriteriji za rad ispitnih laboratorija.

Ministarstvo gospodarstva potom donosi Pravilnik o izmjenama i dopunama Pravilnika o načinu i postupku obavljanja nadzora kakvoće određenih proizvoda pri uvozu i izvozu (NN 108/97). Pravilnik dopušta ocjenu kvalitete drvnih materijala na temelju pregleda (senzorski), a ispitivanja su ostala obvezna samo za ploče iverice. S obzirom na to da ocjena kvalitete drvnih ploča bez ispitivanja ne može biti pouzdana, osobito kad je riječ o slobodnom formaldehidu, izdavanje uvjerenja bez ispitivanja ne može biti učinkovito $u$ kontroli kvalitete.

Tijekom stroge primjene izvornog Pravilnika ispitivana je koncentracija slobodnog formaldehida $\mathrm{u}$ drvnim pločama i u brojnima od njih otkrivena je koncentracija osjetno viša od maksimalno dopuštene emisijskom klasom E1 (maksimalno $10 \mathrm{mg} \mathrm{HCHO/100} \mathrm{g,}$ prema HRN EN 120). U postupcima kontrole kvalitete drvnih ploča LAP-a, od 1993. do 1998 godine otkriveno je 19 ploča emisijske klase E2, devet ploča emisijske klase E3, a četiri ploče bile su izvan emisijskih klasa (Bruči i sur., 1998). Vlada Republike Hrvatske donijela je 25. studenog 1999. godine Uredbu o određivanju proizvoda za koje je potrebno uvjerenje o kakvoći (NN 127/99). Prema toj uredbi, nadzoru kakvoće proizvoda pri uvozu i domaćih proizvoda, prije njihova stavljanja u promet, s područja drvnih ploča podliježu samo ploče iverice. Dakle, ostale drvne ploče uopće ne podliježu nadzoru kakvoće.

\subsection{Osnivanje i rad Tehničkog odbora TO 89}

2.1 Establishment and activities of Program

Committee for wood and Technical Committee 89

Baza za razvoj sustava kvalitete tehnička je regulativa, te stoga u sastavu DZNM-a početkom 1997. godine počinju raditi tehnički odbori (TO). Tehnički su odbori ustrojeni prema ISO sustavu (International Organization for Standardization), odnosno CEN (European Committee for Standardization). Zadaća TO-a je studij međunarodnih normi te izrada prijedloga prihvaćanja u izvornom obliku kao hrvatskih normi (HRN). Preuzimanjem međunarodnih normi, norme bivše države postupno se povlače iz uporabe. TO 89 - Furniri, drvne ploče i drvni poluproizvodi osnovan je u sklopu DZNM-a 22. travnja 1997. godine. Usvojena je struktura TO 89 s tri pododbora (Jambreković, 2003): PO 1 - Furniri i slojevito drvo, PO 2 - Ploče iz usitnjenog drva i PO 3 - Poluproizvodi.

Nakon reorganizacije TO 89 nastavlja rad pod nazivom Furniri i drvne ploče, te s promijenjenom strukturom, koja sada ima sljedeće pododbore: PO 1 Ploče vlaknatice, PO 2 Ploče iverice i PO 3 Uslojeno drvo.

$\mathrm{U}$ početnoj fazi rada, sukladno dobivenim instrukcijama, orijentacija TO 89 bila je implementacija ISO normi. Razvojem novih EN normi započeo je proces povlačenja ISO normi iz uporabe te zamjena ISO normi EN normama (sl. 1).

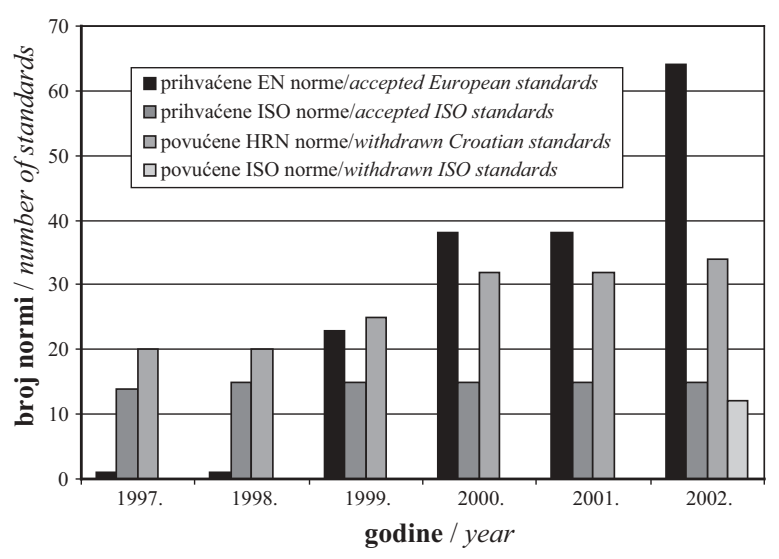

Slika 1. Stanje normi za drvne ploče krajem 2002. godine Figure 1 Status of wood-based panel standards in late 2002

Do kraja 2002. godine prihvaćene su 64 EN norme i 15 ISO normi, a iz uporabe su povučene sve norme bivše države. Neovisno o prihvaćanju gotovo svih međunarodnih normi u certificiranju ploča iverica, norme bivše države ostaju i dalje na snazi. Stoga je Naredbu kao tehničko pravilo trebalo zamijeniti tehničkim propisom utemeljenim na međunarodnim normama.

\subsubsection{Zakonska regulativa kojom sustav kontrole kvalitete drvnih ploča postaje upitan}

2.1.1 Legal regulations that made wood-based panel quality control questionable

Donošenjem Pravilnika o izmjenama i dopunama Pravilnika o načinu i postupku obavljanja nadzora kakvoće određenih proizvoda pri uvozu i izvozu kontrola kvalitete drvnih ploča postaje upitna. Obveza ispitivanja drvnih ploča pri izdavanju dokumentacije o kvaliteti ostala je samo za ploče iverice, koje podliježu obvezi certificiranja. Neovisno o stručnoj osposobljenosti, kvalitetu drvnih ploča nije moguće odrediti vizualnim pregledom, osobito kad je riječ o koncentraciji slobodnog formaldehida (Bruči i sur., 1994). Uredbom Vlade RH o određivanju proizvoda za koje je potrebno uvjerenje o kakvoći s popisa su skinuti svi materijali i proizvodi od drva, osim ploča iverica i namještaja.

Pozivom na zakonsko ovlaštenje koje proizlazi iz Zakona o normizaciji (NN 55/96) DZNM je bio obvezan $\mathrm{u}$ roku tri godine od njegova stupanja na snagu donijeti odgovarajući provedbeni tehnički propis za proizvode koji podliježu potvrđivanju (certificiranju), kao što su ploče iverice. Tehnička je baza postojala, a na području drvnih ploča norme su bile harmonizirane (Jambreković, 2003). Umjesto toga, DZNM donosi Naredbu o izmjenama i dopunama Naredbe o obveznom atestiranju ploča iverica za opću upotrebu i građevinarstvo(NN 131/2000), u kojoj i dalje nisu implementirane EN norme. U nadi da će se pokrenuti donošenje novih tehničkih propisa, nastavljen je rad tehničkog odbora TO 89. Potom slijedi reorganizacija DZNM-a, tijekom i nakon koje su sve aktivnosti bile potpuno zaustavljene, a sustav više gotovo i nije postojao.

\subsection{Reorganizacija DZNM-a}

2.2 Reorganization of SOSM

Tijekom 2003. godine počinje reorganizacija DZNM-a. Zakonom o akreditaciji (NN 158/03) uređuje 


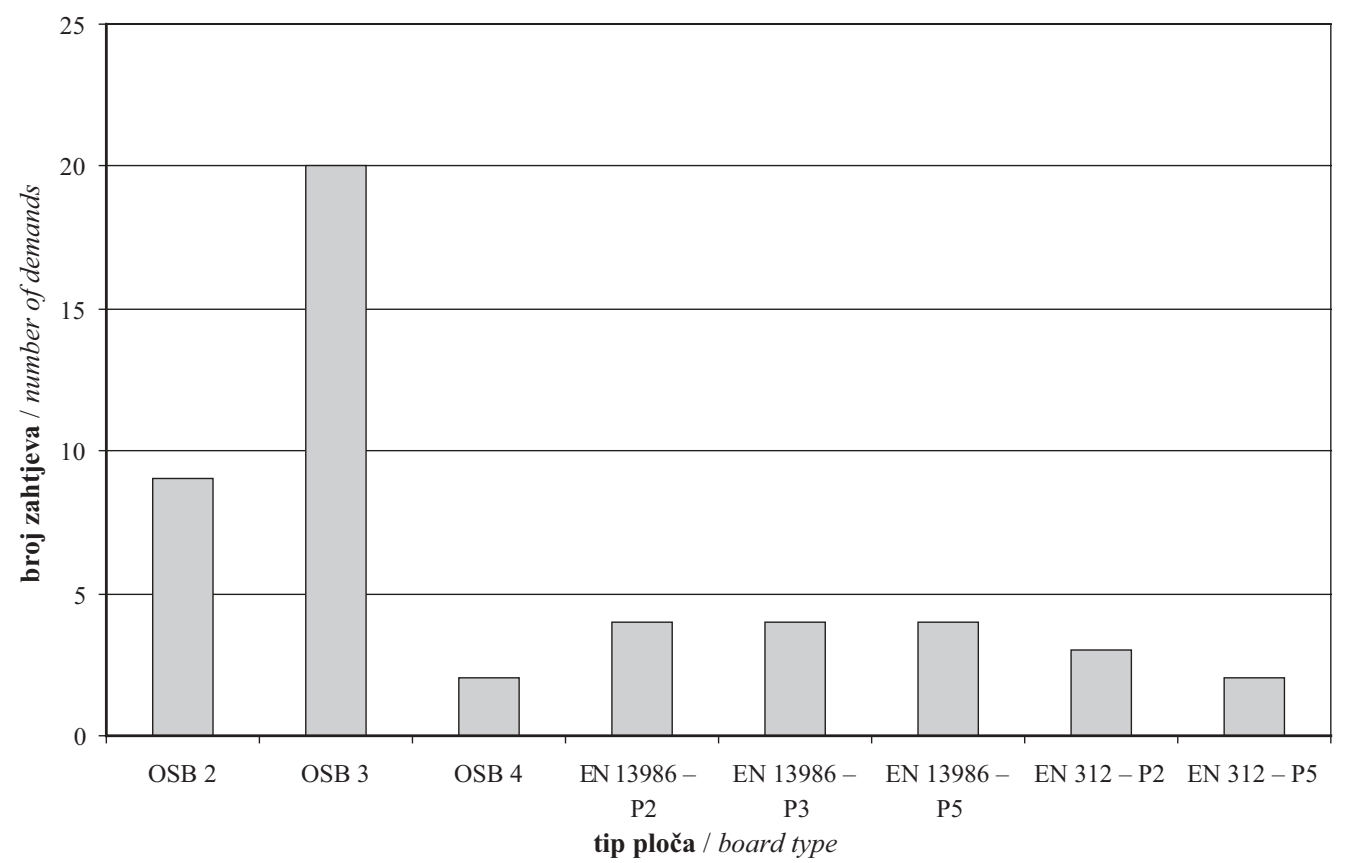

Slika 2. Certificirane ploče iverice deklarirane prema EN normama u razdoblju od 2000. do 2007. godine Figure 2 Particleboard panels certified according to European standards in the period 2000 to 2007

se osnivanje i djelatnost tijela koje obavlja poslove nacionalne službe za akreditaciju, a Zakonom o normizaciji (NN 163/03) uređuju se načela i ciljevi hrvatske normizacije. Uslijedila je Uredba o osnivanju Hrvatskog zavoda za norme (NN 154/04) i Uredba o osnivanju Hrvatske akreditacijske agencije (NN 158/04). Time je DZNM prestao raditi, a nove ustanove više nemaju ovlasti za ovlašćivanje.

Šumarski fakultet, Zavod za tehnologije materijala, ovlašten je od 1995. godine za certificiranje ploča iverica rješenjima DZNM-a, a posljednje ovlaštenje dobio je 9. travnja 2001. godine, na temelju Zakona o normizaciji (NN 55/96). Restrukturiranjem DZNM-a Šumarski fakultet, Zavod za tehnologije materijala, ostao je, s važećim ovlaštenjem. bez nadležne institucije.

Osnivanjem Hrvatskog zavoda za norme (HZN) prethodno formirani tehnički odbori nisu automatizmom nastavili raditi, već su se morali preustrojiti u skladu sa Statutom HZN-a i Unutrašnjim pravilima za normizaciju.

\subsection{Stanje u normizaciji}

\subsection{The situation in standardization}

Od 2002. godine, kada su prihvaćene gotovo sve međunarodne norme na području drvnih ploča i kada se TO 89 polako gasio, na europskoj su se razini dogodile brojne promjene u normizaciji. Mnoge su norme podvrgnute reviziji, a doneseno je i dosta novih. Ostalo je važiti samo 35 normi (od 64 prihvaćene), bilo je potrebno iz uporabe povući 11 HRN EN normi i tri HRN ISO norme koje više nisu postojale, a u postupak revizije staviti 18 HRN EN normi. Na razini CEN-a sredinom 2008. godine, u sklopu CEN TC 112, objavljeno je ukupno 77 normi.

Na prijedlog Tehničke uprave HZN-a do 31. prosinca 2008. godine administrativno su prihvaćene sve EN norme koje pripadaju HZN/TO 89, kao hrvatske norme. Aktivacija i preustroj TO 89 uspijeva tek 20. lipnja 2009. godine, kada ravnatelj HZN-a donosi odluku o novoosnovanom HZN/TO 89.

\subsection{Osnovni problemi u certificiranju prema aktualnoj Naredbi}

2.4 Basic problems in certification according to current Order

Osnovni problemi u certificiranju prema aktualnoj Naredbi o obaveznom certificiranju ploča iverica za opću uporabu i graditeljstvo jesu:

- nije propisano ispitivanje slobodnog formaldehida,

- nije propisano ispitivanje modula elastičnosti savojne čvrstoće,

- pojavili su se novi tipovi ploča iverica,

- nema normi za ploče iverice s makroiverjem (OSB ploče),

- normirana kvalitativna svojstva ploča iverica bitno se razlikuju od dosadašnjih,

- metoda ispitivanja bubrenja ploča iverica bitno je promijenjena.

OSB ploče iverice novi su proizvod na europskome i hrvatskom tržištu, za koje u Naredbi nema normi. Europa sve do 1997. godine, kada su donesene prve EN 300 norme, nije imala norme za OSB ploče. Norme EN 312 daju tehničke specifikacije za sedam tipova ploča iverica s mikroiverjem (od P1 do P7), te se bitno razlikuju od normi prema Naredbi (Jambreković, 2004). Bubrenje ploča iverica prema EN 317 također se bitno drugačije izvodi nego u normama Naredbe. Ispitivanje bubrenja vrlo je važno, jer je evidentan trend povećanja nestabilnosti ploča iverica (Jambreković, 2005). Od 2000. godine, kada je trebao stupiti na snagu tehnički propis za ploče iverice, a koji je trebalo proširiti i na ostale drvne ploče, certificiran je velik broj ploča iverica koje nije bilo moguće deklarirati prema normama iz Naredbe (sl. 2).

Evidentno je da je bilo najviše zahtjeva za certificiranje pojedinih tipova OSB ploča iverica, no sve je 
učestalija pojava zahtjeva za certificiranjem ploča iverica s mikroiverjem, deklariranima prema tipovima $\mathrm{u}$ skladu s normama EN 13986 i EN 312.

\subsection{Ministarstvo zaštite okoliša, prostornog uređenja i graditeljstva}

2.5 Ministry of Environmental Protection, Physical Planning and Construction

Reorganizacijom DZNM-a, poslovi potvrđivanja (certifikacije) ploča iverica 2005. godine prelaze u djelokrug Ministarstva zaštite okoliša, prostornog uređenja i graditeljstva (MZOPUG). Naredba je ugrađena $\mathrm{u}$ Zakon o gradnji (NN 175/03), odnosno u Zakon o izmjenama i dopunama Zakona o gradnji (NN 100/04), a provodi se u skladu s Pravilnikom o ocjenjivanju sukladnosti, ispravama o sukladnosti i označavanju građevinskih proizvoda (NN 1/05). Potom slijedi novi Pravilnik o ocjenjivanju sukladnosti, ispravama o sukladnosti i označavanju građevnih proizvoda (NN 103/08), koji propisuje ustroj laboratorija prema HRN EN ISO IEC 17025:2000.

Tijekom implementacije europske smjernice za građevne proizvode 89/106/EEZ, MZOPU u svoje tehničko zakonodavstvo uključuje i Naredbu o obveznom atestiranju ploča iverica za opću upotrebu i građevinarstvo. Ministrica zaštite okoliša, prostornog uređenja i graditeljstva 20. srpnja 2005. godine daje Šumarskom fakultetu ovlaštenje za obavljanje poslova ocjenjivanja sukladnosti građevinskih proizvoda na temelju članka 26. stavka 1. Zakona o gradnji. Predmet ovlaštenja su ploče iverice za opću upotrebu i upotrebu u graditeljstvu, uz navođenje tehničkih specifikacija baziranih na normama bivše države, a prema Naredbi koja vuče korijenje iz Službenog lista 61/83. U formularima potvrde o sukladnosti navodi se da su značajke proizvoda $u$ skladu sa Zakonom o gradnji i Naredbom o obaveznom potvrđivanju ploča iverica za opću uporabu i graditeljstvo (NN 55/96 i 131/00). Šumarski fakultet 10. srpnja 2007. godine dobiva produženje ovlaštenje za obavljanje poslova ocjenjivanja sukladnosti, a zakonska regulativa ostaje ista. Ovlaštenje vrijedi do 11. srpnja 2009. godine.

\subsubsection{Tehnički propis za drvene konstrukcije (NN} 121/07)

2.5.1 Technical regulation for wooden constructions (Official Gazette "NN" 121/07)

Ministrica zaštite okoliša, prostornog uređenja i graditeljstva 22. studenog 2007. godine donosi Tehnički propis za drvene konstrukcije (NN 121/07). Među ostalim, građevni proizvodi na koje se primjenjuje taj propis jesu i ploče na osnovi drva. U članku 40. propisano je da se nakon 31. prosinca 2008. godine prestaju primjenjivati priznata tehnička pravila za dokazivanje uporabljivosti građevnih proizvoda. U tehničkom propisu za drvene konstrukcije implementirane su HRN EN norme za drvne ploče, uz poziv na priznata tehnička pravila za projektiranje i norme s područja u kojemu postoji samo tehničko pravilo za iverice, a za ostale drvne ploče nema ni tehničkog pravila, ni tehničkog propisa.

\subsubsection{Zakon o građevinskim proizvodima}

2.5.2 Construction Products Law

Hrvatski sabor je 15. srpnja 2008. godine donio Zakon o građevnim proizvodima (NN 86/08). U članku 85. navedenog zakona stoji da se za građevni proizvod za koji nije donesen tehnički propis uporabljivost dokazuje prema priznatim tehničkim pravilima. Od dana prijama RH u EU za dokazivanje uporabljivosti građevnih proizvoda za koje postoji usklađena europska specifikacija prestat će se primjenjivati priznata tehnička pravila sadržana među ostalim, i u Naredbi o obveznom atestiranju ploča iverica za opću uporabu i građevinarstvo. To je još jedan dokument koji produžuje životni vijek Naredbe i omogućuje daljnju uporabu naslijeđenih normi bivše države, usprkos službeno prihvaćenim HRN EN normama.

\subsection{Odluka ustavnog suda Republike Hrvatske}

2.6 Decision of Croatia's Constitutional Court

Odlukom Ustavnog suda Republike Hrvatske od 17. listopada 2007. godine (NN 115/07) Naredba o izmjenama i dopunama Naredbe o obveznom atestiranju ploča iverica za opću upotrebu i građevinarstvo prestaje vrijediti 31. ožujka 2008. godine. U obrazloženju se navodi da je donošenje izmjena i dopuna propisa donesenoga na temelju drugog zakona (koji je u međuvremenu prestao vrijediti) suprotno izričitoj odredbi Zakona koja nadležno tijelo obvezuje na donošenje novih provedbenih propisa. Dakle, tom je odlukom stavljena izvan snage ne samo Naredba o izmjenama i dopunama, nego i izvorna Naredba (Službeni list 61/83). Time je nastao vakuum u poslovima certificiranja ploča iverica jer je stara Naredba izvan snage, a novi tehnički propisi usklađeni sa smjernicama Europske Unije nisu izrađeni.

\subsection{Izrada Tehničkog propisa za drvne ploče \\ 2.7 Preparation of Technical Regulation for wood- based panels}

$\mathrm{Na}$ inicijativu Ministarstva regionalnog razvoja, šumarstva i vodnoga gospodarstva (MRRŠVG), Uprave za drvnu industriju, ministar MRRŠVG-a donio je 3. rujna 2008. godine rješenje o osnivanju i imenovanju Povjerenstva za izradu tehničkih propisa za drvne ploče. Prihvaćanjem i primjenom Tehničkog propisa RH će uspostaviti tehničku regulativu za nesmetani promet drvnih ploča te osigurati kvalitetu drvnih ploča sukladno HRN EN normama. U pripremi prednacrta Tehničkih propisa dolazi do nesuglasica zbog stajališta da je ta problematika, kad je riječ o području graditeljstva, riješena u postojećoj tehničkoj regulativi. Na petom sastanku postignut je dogovor o izradi Tehničkog propisa za drvne ploče, uz zaključak da će tehnički propis obuhvatiti područje opće uporabe drvnih ploča. Tehnički propis za drvne ploče za opću uporabu rađen je u skladu sa Zakonom o tehničkim zahtjevima za proizvode i ocjeni sukladnosti (NN 158/03,79/07). Konačni nacrt prijedloga Tehničkog propisa za drvne ploče našao se na dnevnom redu 23. rujna 2009. godine. Nakon rasprave bilo je evidentno da još uvijek nisu jasna polazna stajališta pojedinih ministarstava te da Povje- 


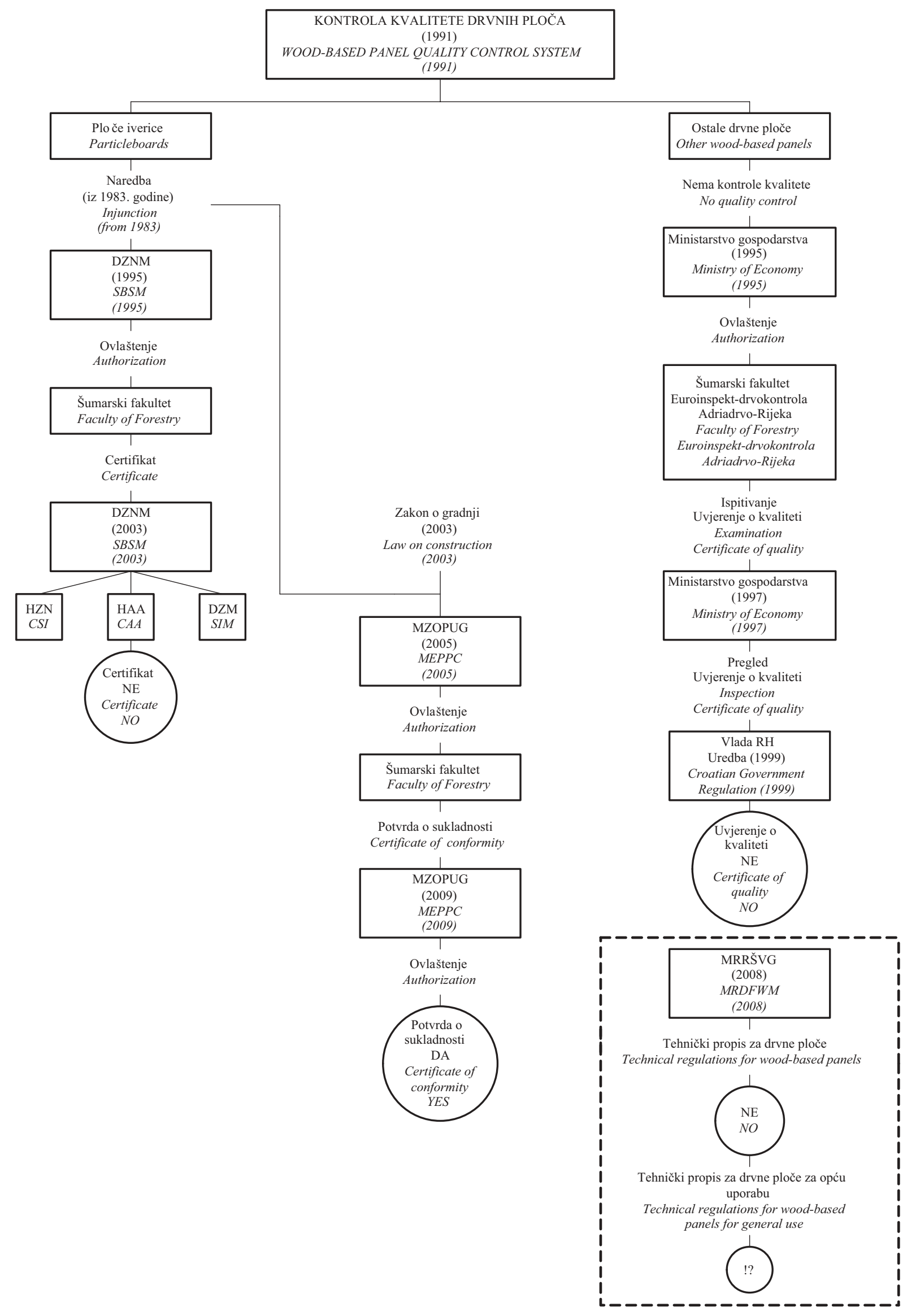

Slika 3. Razvoj kontrole kvalitete drvnih ploča

Figure 3 Dewelopment of wood-based panel quality control 
renstvo neće moći pripremiti tehnički propis bez usuglašavanja stajališta MZOPUG-a i MRRŠVG-a.

\section{OSVRT NA STANJE SUSTAVA}

3 OVERVIEW OF SYSTEM STATUS

Sustav kontrole kvalitete drvnih ploča kvalitativno se razvijao od 1993. godine do 1999. godine (sl. 3). Gašenje sustava započelo je Ministarstvo gospodarstva, koje 1997. godine donosi odluku o izdavanju uvjerenja o kvaliteti drvnih ploča (osim iverica) na temelju pregleda, bez ispitivanja. Potom Vlada RH 1999. godine donosi odluku da za drvne ploče pri uvozu ne treba uopće nikakvo uvjerenje o kvaliteti.

DZNM se transformira i gasi, a poslovi ovlašćivanja više nisu u djelokrugu novoosnovanih institucija. Od 2003. godine Šumarski fakultet ima važeće rješenje o ovlaštenju za certifiranje ploča iverica, ali nema nadležne institucije. Prvi pozitivan pomak u ponovnoj uspostavi sustava kontrole kvalitete bio je 2005. godine, kada MZOPUG preuzima pod svoju ingerenciju Naredbu, te ovlašćuje Šumarski fakultet za provedbu postupaka potvrđivanja sukladnosti ploča iverica za opću uporabu i graditeljstvo. MZOPUG donosi niz zakona i propisa u kojima su obuhvaćene i drvne ploče, ali ne nalazi načina za rješavanje Naredbe iz 1983. godine.

Ustavni sud donio je odluku o ukidanju Naredbe o izmjenama i dopunama Naredbe o obveznom atestiranju ploča iverica za opću upotrebu i građevinarstvo. No u tumačenju se navodi da o izvornoj Naredbi nije odlučivano, pa iz toga proizlazi da se prema njoj i dalje postupa.

Zakonom o građevnim proizvodima i Tehničkim propisom za drvene konstrukcije (NN 121/07), spornoj je Naredbi produženo trajanje na neodređeno vrijeme.

Aktivnošću MRRŠVG-a pokušao se izraditi tehnički propis za drvne ploče, ali još nisu riješene nesuglasice vezane za nadležnost pojedinih ministarstava glede primjene drvnih ploča u općoj uporabi, ali i u graditeljstvu.

\section{ZAKLJUČAK 4 CONCLUSION}

Naredba o obveznom atestiranju ploča iverica za opću uporabu i graditeljstvo s tehničkog stajališta je neodrživa, jer se nije bitno mijenjala punih 25 godina.

Zbog intenzivnog razvoja novih tipova ploča, novih ekoloških zahtjeva i usavršavanja ispitnih metoda certificiranje pojedinih tipova ploča prema spomenutoj Naredbi neizvedivo je.

Spornu Naredbu o obaveznom atestiranju ploča iverica za opću upotrebu i građevinarstvo (S1. list 61/83), koja je i Odlukom Ustavnog suda Republike Hrvatske stavljena izvan snage potrebno je isključiti iz svih tehničkih dokumenata.

Područje certificiranja ploča iverica trenutačno je u zakonski nereguliranom području, što može imati vrlo negativne posljedice za gospodarstvo Republike Hrvatske.

Nužno je usmjeriti napore na razvoj sustava kontrole kvalitete drvnih ploča radi zaštite potrošača drvnih ploča i proizvođača finalnih drvnih proizvoda.

Hrvatska gospodarska komora i ministarstva moraju podržati rad HZN/TO 89 - Furniri i drvne ploče, stručne se institucije moraju intenzivnije uključiti u njegov rad, a gospodarstvenici moraju shvatiti da put u EU vodi preko uređenog sustava tehničke regulative.

U Ministarstvu regionalnog razvoja, šumarstva i vodnoga gospodarstva treba ponovno potencirati izradu Zakona o preradi drva na kojemu se treba temeljiti sustav kontrole kvalitete drvnih materijala.

Povjerenstvu za izradu tehničkog propisa za drvne ploče za opću uporabu treba omogućiti izradu tehničkog propisa za sve drvne ploče.

Tehnička regulativa vezana za drvo i drvne materijale treba biti u djelokrugu Ministarstva regionalnog razvoja, šumarstva i vodnoga gospodarstva, pod ingerencijom Uprave za drvnu industriju.

\section{LITERATURA}

\section{REFERENCES}

1. Bruči, V.; Janović, Z.; Jambreković, V.; Brezović, M., 1994: Određivanje formaldehida iz drvnih pločastih materijala perforatorskom metodom, Zagreb: Šumarski fakultet.

2. Bruči, V.; Salah-Omer, E.; Jambreković, V., 1998: Certification and quality Attestation of woodbased panels. 1st International Conference "A Perspective of WodworkingIndustrial System in Bosnia and Herzegovina", Proceedings 183-193, Bihać.

3. Hägglund, B.; Beckeman, C.G.; Björnberg, C.G.; Borgström, B.; Härmälä, E.; Presas, T.; De Jaeger, F.; Hufnagl, N.; Gädda, L.; Birot, Y.; Sahi, A., 2005: A technology platform initiative by European forest-based sector, Vision 2030. Brussels: CEI-Bois, CEPF, CEPI, European Commision.

4. Jambreković, V., 2003: HRN EN norme za drvne ploče. Tehničko usklađivanje na putu prema Europskoj uniji. Hrvatski inženjerski savez, Državni zavod za normizaciju i mjeriteljstvo, 337-344, Zagreb.

5. Jambreković, V., 2004: Drvne ploče i emisija formaldehida, Šumarski fakultet, Zagreb.

6. Jambreković, V.; Antonović, A.; Medved, S., 2005: Quality of particleboards for the production of furniture and interior decoration. Furniture and equipping of interiors, Faculty of Forestry, University of Zagreb, 111-116.

\section{Corresponding address:}

Assoc. Prof. VLADIMIR JAMBREKOVIĆ, Ph.D.

University of Zagreb, Faculty of Forestry

Department of Wood Technology

Svetošimunska 25

10000 Zagreb, Croatia

e-mail: vladimir.jambrekovic@zg.htnet.hr 